\title{
Bringing Environmental Education to the Curriculum: Practical Elements Emergent from Teaching Experiences and Research
}

\author{
Julio César Tovar-Gálvez ${ }^{1^{*}}$
}

${ }^{1}$ Martin-Luther-Universität Halle-Wittenberg, GERMANY

*Corresponding Author: joule_tg@yahoo.com

Citation: Tovar-Gálvez, J. C. (2021). Bringing environmental education to the curriculum: Practical elements emergent from teaching experiences and research. Interdisciplinary Journal of Environmental and Science Education, 17(3), e2236. https://doi.org/10.21601/ijese/9606

\begin{abstract}
ARTICLE INFO
ABSTRACT

Received:

8 July 2020

Accepted:

6 September 2020

Bringing theories or policies about environmental education into the classroom is a common problem that teachers must confront. The purpose of this paper is to provide teachers with practical elements emergent from teaching experiences and research. A Complex Environmental Formation framework is proposed to curricularize a self-eco-organized understanding of the environment and being. Methodologically, three cases are studied using in two methods - a content analysis to identify emergent teaching elements, and a conducted analysis using the framework. The analysis and results indicate some potentially transferable teaching elements -a) selecting local environmental situations to contextualize curriculum, b) integrating knowledge for reading/transforming reality, c) guiding teaching and learning through questions, d) competence-based teaching and learning, e) project-based teaching and learning, f) assessing cooperatively and with formative purpose, g) addressing environmental education from different educational approaches, and h) breaking institutional barriers. There is an approximation to self-eco-organize the subject, communities, institutions, knowledge, learning, teaching, and assessment.
\end{abstract}

Keywords: educational practice, environmental education, environmental pedagogy, environmental didactics, complexity

\section{INTRODUCTION}

Bringing to the curriculum theories and policies about environmental education (EE) is a problem for teachers, because it is not always clear how to move from ideas to practice (Briggs, Trautmann \& Fournier, 2018; Dyment, Hill \& Emery, 2015; Geli, Collazo \& Mulà, 2019; Gutierrez-Sabogal, 2015; Marques, Gonzalez \& Xavier, 2016; Meyers, 2006; Paredes-Chi \& Viga-de Alva, 2018; Sanuca, 2018; Tian \& Wang, 2016). In the same way, in the research field of EE, the curriculum environmentalization or curricularization of theories and policies about the environment are still considered a problem (Dannenberg \& Grapentin, 2016; Erdoğan, Kostova, Marcinkowski, 2009; Eschenhagen, 2011; Fuentes \& González, 2016; Gutiérrez \& González, 2005; Burmeister \& Eilks, 2013 a; KhademiVidra, 2017; Stevenson, 2007; Winter \& Cotton, 2012). A part of the practical and research problem is that there are no specific or explicit theories of environmental pedagogy and environmental didactics (Parga \& Mora,
2016; Tovar-Gálvez, 2013). This lack has an impact since curricularization is the process of expressing theories and policies about EE in pedagogical and didactic terms.

However, on both mentioned fronts there are advances (Abril, 2011; Arredondo, Saldivar \& Limón, 2018; Burmeister \& Eilks, 2013 b; Calvo-Cruz, 2013; Mora, 2015; Oliveira \& Sá, 2017; Tovar-Gálvez, Téllez-Acosta, \& Martínez, 2017). These advances provide conceptual and practical elements for an EE curricularization. The purpose of this paper is to provide teachers with practical elements emergent from teaching experiences and research on complex environmental education (TovarGálvez, 2020a, b, based on Morin, 1996, 1998, 2004).

Illustrating teachers on how to bring EE theories into the classroom through practical elements contributes to solving some problems. One, already stated, has to do with making theoretical and normative ideals operational in the classroom. This does not imply giving teachers recipes and limiting their critical and creative capacity. Rather, it seeks to offer teachers elements that do not depend on 
the content or a specific context but can be transferred and adapted to other educational settings. The same is implicit in the complex vision of EE, which focuses on transformative relationships, processes, and actions (Ardoin, Bowers, Wyman \& Holthuis, 2018). Practical elements emerging from experience and research do not depend on content and cases, which demonstrates that $E E$ is not limited to the natural sciences (Briggs, et al., 2018; Demoly \& Santos, 2018; Marques, et.al, 2016). Another contribution is at the research level by providing more data, whether obtained inductively or deductively, that expand the corpus for EE theories available or under construction. This paper displays data and a frame that potentially contributes to the consolidation of the Complex Environmental Formation Theory (Tovar-Gálvez, 2020a, b).

To provide teachers with practical elements for a complex EE, the structure of this paper consists of two parts. First, the framework describes a proposal for a Complex Environmental Formation. This frame presents a philosophical basis defining a complex understanding of the environment and being, which will be curricularized (translated into pedagogical and didactic terms). Second, the systematization of the three educational processes unveils possible generalizable or transferable practical teaching elements. Systematization consists of reconstructing, organizing, and communicating the experiences, followed by content analysis to identify emergent categories. Additionally, detailed analysis was conducted on the experiences regarding how the cases meet the framework.

\section{Complex Environmental Formation as Framework to Curricularize}

The basis is a complex understanding of Environment and Being (Tovar-Gálvez, 2020a, b, based on Morin, 1996, 1998, 2004) to bring into the curriculum. The Environment is a system of systems, emerging from the self-eco-organization between the social system and the biophysical system. Self-organization refers to the internal relationships between the elements of a system, which gives emergent properties to the system. Ecoorganization alludes to external relationships between systems, which confers unique emergent properties to the system of systems. The Being is a self-ecoorganized system, related interdependently with others, conforming communities, societies, cultures, peoples, nations. This emergent social system is related inevitably with and into the biophysical system. Thus, humans are part of nature, are interrelated, and for this reason, they influence and are influenced by the biophysical system. In this way, human decisions and actions into particular and historical biophysical contexts produce different environments. Then, the emergence of an environmental phenomenon that risks social-biophysical viability is a human construction, as an effect of human ways of living. Assuming the environment as non-determined, not given, but as a possibility to build, opens the opportunities to new life and existence projects, to construct alternatives to the prevailing consumerist way of life.

The next curricularization step is taking the complex understanding of Environment and Being, and bringing it into the educational field, by proposing the Complex Environmental Pedagogy -CEP- (Tovar-Gálvez, 2020a, b). The CEP is the theory, praxis, and reflections through which communities might self-eco-organize institutions and subjects with the aim of the environmental transformation. This self-eco-organization is reached through a planned and intentional mobilization of culture between subjects, to construct other environmental realities. Therefore, communities use or transform their beliefs, traditions, ways of communicating, knowledge, epistemologies, ways of acting, values, experiences, feelings, etc., which influence on the social and biophysical systems. The participants of this act are related cooperatively, for mutual learning-construction, and joint action. The curriculum is a process through which educational institutions and communities seek to contribute to the construction of the citizen profile. This is a citizen who transforms the relationships human-human and human-rest-of-nature to build new environments.

The last curricularization step is taking the complex pedagogical understanding of subjects and institutions, and bringing it into practice, by proposing the Complex Environmental Didactics -CED- (Tovar-Gálvez, 2020a, b). The CED is the theory, praxis, and reflections through which communities might self-eco-organize the learning, teaching, and assessment with the aim of the environmental transformation.

The learning is defined, developed, and regulated through the Complex Environmental Competence CEC. The CEC is the subjects' self-eco-organized action, which is a product of the relationship and conscious use of multiple possibilities of the Being, to transform the environment. Those multiple possibilities are the components (see Table 1) - a) cognitive, which encompasses conceptual, procedural, attitudinal, communicative and epistemic knowledge from different disciplines and thought systems, aimed at transforming environmental reality, b) metacognitive, which includes the conscious reflection, administration, and assessment on their own learning, c) contextual, which consist in the collective learning and cooperative work, d) contextual, which engages communities in transforming local 
Table 1. Complex environmental competence

Complex Environmental Competence-CEC- for high school

The student leads processes of community education and management of non-viable socio-biophysical situations, based on school and community knowledge, seeking to build more viable environments.

Components of CEC

Conceptual

Procedural

Cognitive Attitudinal

Communicative

Epistemic
Example of possible students' performance

Student describes non-environmentally-viable situations by using scholar and community knowledge.

Student develops strategies for managing sources, information, processes, actions, etc., for achieving more environmentally-viable situations.

Student reflects critically on the implications of human ways of relating (social systembiophysical system).

Student communicates in writing his/her learnings about more environmentally-viable situations, by using the language of the different kinds of knowledge (school subjects).

Student develops managing strategies integrating diverse kinds of knowledge, ways to know, organizational ways and participants, reflecting a complex way to produce knowledge about the environment.

Student assesses his/her cognitive possibilities in terms of how those contribute to more environmentally-viable human ways of relating.

Student shares with others her/his learning about more environmentally-viable human ways of relating.

Student addresses non-environmentally-viable situations in his/her learning place and home.

Student reports evidence of contributions to the environmental transformation in his/her learning place and home.

Student reflects on his/her role as a person and citizen, regarding the kind of environment that he/she wants to construct.

Extracted and adapted from Tovar-Gálvez (2020)

environments, e) factual, which represents the real impact on the transformation of reality, and d) identity, which involves subjects' reflections as citizens, students, professionals, etc.

In Complex Environmental Didactics, teaching is planned, enacted and regulated through projects. By developing projects, teachers generate conditions for students to build their CEC when dealing with local environmental situations, from diverse kinds of knowledge and multiple ways of proceeding, as well as from different forms and levels of organization and cooperation (Tovar-Gálvez, 2020a, b). Assessment is understood as a collective, reflective, formative, and transforming process of knowledge production about environmental educational processes, through the identification of different expressions of complexity in the educational processes (Puerto \& Tovar-Gálvez, 2020).

\section{METHOD}

The study of the three educational experiences related to EE aims to identify practical teaching elements. Such elements have the potential to contribute to teachers and their contexts. This is a qualitative study that consists of two parts. The first part displays, as data to be analysed, an approach to the systematization of experiences (Cárdenas \& Suarique, 2010; Jara, 2012) -reconstruction, organization, and communication of the educational processes. The second part is a conventional content analysis to identify emerging categories (the practical teaching elements), and then a directed content analysis to interpret the experiences using the a priori framework as criterion (Hsieh \& Shannon, 2005).

The study of cases as a methodology provides different possibilities - a) identification of experiences' specific characteristics leading communities to provide feedback on such processes, b) identification of experiences' general elements which potentially might contribute to other contexts, c) providing data that contribute to understanding general problems or to support theories (Díaz, Mendoza \& Porras, 2011). Two of the cases took place in higher education, as lessons for engineers and teachers, and the third case is a project proposal for a 
school. The cases are developed by the same teacher, to articulate environmental education to the teaching practice but supporting this articulation from different educational approaches.

Thesystematization of experiencesisanepistemological process alternative to research, but complementary (Jara, 2012). It aims to produce knowledge from the experiences already lived by communities. During the dynamic the community reconstructs and critically reflects on its experience, identifying learning and opportunities to transform reality. The data are the systematic narrations, interviews, documents and memories. The analysis is inductive, so it produces emerging categories from the context. These findings are contrasted or discussed with existing frameworks. The products are a contextualized, but potentially transferable or adaptable theory, and new horizons for the enhancement of the experiences. Traditionally, social movements and organizations systematize their experiences supported by researchers from social work, adult education and community education (Falkembach \& Torres, 2015). As an example, ActionAid (2009) publishes the systematization of some experiences of social movements from different countries in America, as examples of social transformation.

This author, as a participant of the educational processes, reconstructs, organizes, and communicates each experience, and identifies emergent categories which constitute learnings. According to the aim of the paper, learnings here are the practical elements for environmental education. The expectation is that teachers use these elements as an alternative for transforming their $\mathrm{EE}$ experiences. Although these findings emerge from specific cases, they are described as general processes and discussed with research reports on the same topic. For this reason, the practical elements do not depend exclusively on the cases and have the potential to be transferable or adaptable to other contexts.

\section{Population}

The first case is a real experience lived in a private university in Bogotá (Colombia). The educational process is a chemistry seminar offered to a group of 45 engineering students (systems, electronic, and automatization). The students are in their first semester and are between 16 and 25 years old. The second case is a real experience lived in a public university in Bogotá (Colombia). The educational process is a chemistry seminar offered to a group of 38 bachelor students in teaching biology. The students are in their first semester and are between 15 and 21 years old. The third case is a hypothetical experience in a school in Bogotá (Colombia). The educational process is a transdisciplinary proposal for a whole school. Although it is a proposal, the environmental context later described is a real situation in the city. The social troubles, as well as the educational challenges of the communities around the city landfill, are authentic.

\section{Information Sources, instruments, and Data Collecting}

The information sources are the chemistry seminar syllabus, project planning, guides of activities designed by the teacher, and the teacher testimony (who is also the researcher). A general structure organizes the information regarding the three experiences. Thus, the instrument to process information is a form to identify some parts of every case - a) objective, b) teacher's initial theoretical assumptions, c) experience process: planning and development, and d) table describing planning. The data are the systematic narration of each educational process.

\section{RESULTS}

\section{Systematization of Case 1. Chemistry for Engineers: The Problem of Tires}

- Objective: To guide students in using chemistry and metacognitive processes to understand and solve an environmental problem, through a semester project.

- Initial theoretical assumptions: In this process the author utilizes Ausubel's Assimilation Theory (Ausubel, Novak \& Hanesian, 1978), inquiry-based teaching and learning (Vásquez, Becerra \& Ibáñez, 2014), relations between Science, Technology, Society, and Environment (Solbes \& Vilches, 2004), and experiences with metacognitive processes (Tovar-Gálvez, 2012). The metacognitive reflection and problem identification process is articulated in the first part of the project. In the same way, the metacognitive administration is linked to the problem solving proposal during the second part of the project. Finally, the metacognitive assessment is integrated with the development of the problem-solving proposal during the remainder of the project.

- Process:Asa rule of the university where the experience happens, the semester consists of four periods with the same distribution of contents. The university regulates this through unified and simultaneous examinations, assuring that students in all chemistry courses address the same topics at the same time. The problem of tire accumulation in big cities was chosen as a motivating problem. A general question and four specific questions were formulated to guide students through the use of the chemistry contents of each period to understand and solve the problem. The combination of metacognitive processes and the stages of solving the project (to be carried out by teams of students) is how the process was directed and the activities were designed (see Table 2). 
Table 2. Activities proposed at the beginning of the educational process

Phase 1: Metacognitive reflection / Project problem and hypothesis

Activity 1 . Students make a conceptual map using a list of concepts of the first academic period. This is a source to assess students' initial conceptions.

Activity 3. Students have access to a varied list of possible sources, means, or tools that might support their learning. Such options are ideas to improve their learning processes.

Activity 5. Students read a text on the problem of tire accumulation in the big cities of the world. They are motivated to underline in the text concepts that they do not understand.
Activity 2 . Students make a list with the concepts that they could not include in the conceptual map due to their incomprehension.

Activity 4. Students write about their ideas on tire accumulation, contributions to solve the problem as engineers, and the possible use of chemistry.

Activity 6 . The teams formulate a hypothesis to solve the question -what is the tire components' microscopic structure, and to what extent can chemical treatments give them use or eliminate them?

Phase 2: Metacognitive administration / methodology to solve the problem

Activity 7 . The work teams are oriented to elaborate action strategies, contemplating activities both in class and extra curricular. Through this, students might learn those previous concepts that they identified as difficult (Activity 2), approach the concepts related to the problem (Activity 5), learn more about the context and assess the hypotheses.

Phase 3: Metacognitive assessment / assessment of the achievement

Activity 8. Students are guided to assess the success of their action strategies. The report includes a description of the activity, assessment of the activity's contribution to achieving the objectives, and a list of undeveloped activities with explanations..

Activity 9. At the end of the whole process, students have access to a guide with criteria to develop a global assessment. For this, students should use the first conceptual map, periodical reports on the action strategies, and the final conceptual map. Own elaboration

Metacognitive Reflection: The aim is for students to recognize their resources, possibilities, difficulties, and opportunities in learning. From here, students are motivated to define the problem and to state a hypothesis for solving it. With this connection, metacognitionproblem, students reflected on how much they know about the problem and solution.

Metacognitive administration: The aim is for students to articulate a learning/solution strategy. The learning part of the strategy encompasses activities to learn about both chemistry and the problem. The solution part of the strategy comprises activities aimed at changing the environmental context using chemistry. This integration between metacognition and possible problem-solution motivates the project's methodological and experimental design phase.

Metacognitive Assessment: The aim is for students to assess the achievement of the objective. Students identify the viability and contribution of the proposed activities. This relationship between assessment and strategy motivates the project evaluation phase. The process is permanent, and students develop a global assessment at the end.
Systematization of Case 2. Chemistry for Biology Teachers: The Problem of Contamination of The Water Bodies in Bogotá

- Objective: To guide students in using chemistry contents to understand and solve an environmental problem, promoting their strategic learning through a project during the semester.

- Initial theoretical assumptions: To develop this experience, the author was interested in promoting students' strategic (procedural, methodological, or administrative) dimensions of learning (Tovar-Gálvez \& Cárdenas, 2012). Therefore, the author proposed to students some elements as working roles, types of activities, working schedules, organization of learning products, design of practical works, articulation of activities, and assessment of the process. The students were engaged in a project to address an environmental problem via chemistry.

- Process: The academic semester is also divided into four periods, but the contents are not controlled by unified exams. The problem of contamination of Bogota's water bodies (wetlands, rivers, streams, and lakes) was chosen. A general question was proposed, in addition to four more questions that would lead students to use the chemistry contents of each period to understand and solve the problem (see Table 3). It was suggested to student teams that they focus their work on a body of water according to 
Table 3. Teacher's first academic period planning in the semester.

Integrator Problem

How can we contribute to solving the problem of waste accumulation in the Bogotá's water bodies using chemical knowledge?

Guiding question for the first academic period

What mechanical, chemical and biological processes can be used to treat the materials considered waste?

Contents

- Water bodies in Bogotá context

- Solubility

- Concentration

- Colligative properties

- Chemical change

Own elaboration

their interests. The general moments were:

Beginning: The first activity was the assessment of students' prior knowledge about chemistry and the context of the problem. Other activities were the design of action strategies to address the problem and the assignment of roles defined by specific responsibilities. Students counted on supporting tools to develop such strategies and roles. Likewise, students wrote about their commitment to the problem as future biology teachers.

During: Each lesson was divided into two parts. During the first part, chemical theories and how to use them to understand the context of water bodies and pollutants were addressed. During the second part, student teams worked on developing the planned activities (to learn chemistry, understand the context, and interpret the context from chemistry). They should finish with a product (schemes, synthesis, diagrams, conceptual maps, attempts to answer the questions, etc.). The projects consisted of planning, development, and assessment of the activities (their integration and contribution to solving the problem). Students assumed and interchanged working roles according to administrative tasks: management of the portfolio (with the products), collecting and distributing information, products' registration, and assessment forms fulfilment, among others. However, all the participants jointly developed the activities, products, and answers to questions.

Assessment: Each stage of the project was guided by supporting tools. In this order, students counted on criteria to assess developed activities and also working roles. In the end, students used a tool to guide global self-evaluation.

\section{Systematization of Case 3. Beyond The Natural Science Class: Crisis in Doña Juana Sanitary Landfill in Bogotá}

- Objective: To guide a school in making environmental education transversal for each subject, taking into account the context in which the institution is located.
- Initial theoretical assumptions: It is a proposal to develop in a school. The framework is a complex complex understanding of education (Morin, 1999), and the orders of knowledge ecologization (Morin, 1996) to read and transform reality -disciplinary, multidisciplinary, interdisciplinary, transdisciplinary, and interepistemology. A project is a way to put such a frame into practice. The aim is to transform a local environmental problem integrating different subject-matters. The project is a process to organize the community, articulate the disciplines, and to guide the cooperative work between teachers and students.

-Process: Teachers start by identifying a local environmental problem and then they direct the curriculum towards the solution of this problem. Then, teachers formulate a set of questions (see Table 4) to motivate students to interpret and transform the problem through each subject. The questions' purpose is to connect content and problem. It is a contextualization of the content. As an example, I use the case of Doña Juana Landfill (the city's main rubbish dump) in the south of Bogotá. Several neighbourhoods are affected due to the emission of gases, leachates, and pest proliferation. In 1997 there was a landslide of approximately 600.000 tons of rubbish, leaving the entire city on red alert. In 2015, there was another slip of 750 tons. Currently, the State has not yet compensated the affected communities.

Beginning: The case and the set of guiding questions for each subject-matter are presented. Teachers must decide their organization possibilities for the project -by subject-matters, departments, courses, groups, or educational levels, but always with an eye to addressing the same problem as part of a general project of the educational institution. Starting from the questions, teachers can motivate students in the use of disparate disciplines to understand the environmental context and look for alternatives for its transformation.

During: The proposal is to organize the community 
Table 4. Set of questions by subject-matter around the landfill problem

Objective by area of knowledge Set of questions that might guide the interpretation of the environmental situation

Natural Sciences:

Understanding of the biological, chemical and physical dimensions of environmental situations.

- Community health: What are the public health problems present in the communities of Ciudad Bolívar, Usme, and Tunjuelito, close to the landfill? What are the main transmissionvectors existing in the landfill context?

- Bio-chemical composition and processes: What are the alternatives for biodegradation? What microorganisms are there? What is the composition of the main materials thrown into the landfill? What substances are derived from the decomposition of the materials into the landfill?

- Soil and water pollution: What is the underground water pollution process? How are leachates handled?

Social Sciences:

Understanding of the economic, political, social, health, food and cultural contexts associated with environmental situations.

\section{Human Sciences:}

Development of communication, dissemination and education processes.

Recognition of the being in the environmental situation.

Sports science:

Understanding of the relationships between identity, health and sport in the particular environmental situation.

\section{Mathematics:}

Quantitative reading of the situations.

Information collection, management and analysis systems.

Business training: Understanding of the relationship between industry and social-biophysical aspects. Ethical aspects of economic development.

- Community characterization: What are the characteristics and histories of the communities that live near the landfill? What characterizes the identity of people that are part of the communities rooted in the territory of the landfill? What are the imaginaries of the communities facing the landfill and its management?

- Policies, institutions and community: What regulations exist around the landfill process? How is citizen participation in the administration and development of regulations around the landfill? What tensions exist between the landfill administration and communities? What is the current situation of people who collect in the landfill for recycling?

- Information, media and the environmental context: What are the information sources about the landfill? What are the speeches around the landfill? What is the role of the media regarding the landfill debate? What are the means of communication between the communities with respect to the landfill?

- Community and communication: How to guarantee access to technical information to the community? How to establish ways of community communication?

- Communication and leaning: How to achieve a complex understanding of the environment through the local media? How to guide students to build analytical, informative, technical, and other types of documents from each subject-matter?

- Community health: How does the contamination emanating from the landfill affect physical development? What are the main diseases that occur due to air and water pollution? What diseases occur due to food from contaminated soils?

- Community attitudes: What relationship can there be between self-esteem and attitudes towards the rubbish issue and the context of the landfill?

- Alternatives: What are the alternatives for physical education of schools and communities located in the territory of influence and high impact of the landfill? How to ensure nutrition with food free of contaminants?

- Analysing data from the environmental context: How to design information collecting instruments to obtain and analyse quantitative data? How to interpret the statistical reports related to the landfill context? How to make statistical studies on the populations, types of waste, leachates discharged, costs, production of waste in homes, etc.?

- Community education: How to educate the community to interpret quantitative information regarding the environmental context?

- Policy, ethics and development: What are the regulations regarding waste management in the industry? What is the social responsibility of the industry? What are the ethical implications of economic development?

- Alternatives: What waste management alternatives are relevant to each type of industry? How can waste be turned into something productive? How to improve production processes to generate less waste? What are the alternatives to better manage the landfill?

- Environment emerging of systems interaction: What are the elements, dynamics, and processes that characterize the complex landfill environmental context?

- Knowledge self-eco-organization: What activities and relations between different kinds of knowledge contribute to change the landfill environmental context?

All subjects action regarding the environment? How to involve other sectors of the community in understanding and action on the landfill? 
in a double-aim system, engaging it with a common purpose, but promoting specific interests (Mejías, 2015). In this case, the common purpose is the environmental situation to be transformed. And the specific interests are what each subject-matter chooses as content to solve the problem. The project, based on the question set, is a possible dynamic to organize the community internally and externally.

Assessment: The organization system also requires an assessment system that helps participants to identify achievement, regulate the process, and redefine new paths, if necessary, and new stages of the process (Puerto \& Tovar-Gálvez, 2020).

\section{ANALYSIS AND DISCUSSION \\ Conventional Content Analysis: Emerging Practical Teaching Elements}

After systematizing the three experiences, it is now possible to identify some emerging categories. They are practical elements because teachers might use them to guide environmental education processes. Such elements are emergent because they are present during the experiences and are patterns in the teaching practice.

Selecting local environmental situations to contextualize curriculum. In all three cases, the aim is to integratelocalenvironmental problemsintothecurriculum -accumulation of tires, contamination of water bodies in the city, and the issues concerning the local landfill. In this way, teachers acquaint students to their contexts, making content more meaningful, and encourage students to change their reality. Contextualization is relevant, as some studies on school environmental projects reveal that sometimes the educational communities do not attempt to understand and transform the same scenarios in which they are immersed (Restrepo, 2013).

Integrating knowledge for reading/transforming reality. In the first two cases, communities interpret environmental reality from a specific discipline. In the last case, the proposal is to understand the context from the multiplicity of disciplines and interdisciplinary perspectives. Reading and approaching environmental issues requires more complex perspectives, such as interdisciplinarity, which provide greater comprehension and intervention capacity than isolated disciplines (Carvajal, 2010). This position also provides significant results in terms of a better understanding of the problems by students (Torres, Messina, Salamanca \& Sepúlveda, 2016).

Guiding teaching and learning through questions. In all three experiences, the question integrates the environmental problem in the curriculum and motivates students' learning and performance. The question is useful in teaching and learning because it facilitates the dialogue between teachers and students, presents a challenge, and motivates students to better understand a situation (Morón, 2015). The question is an instrument for teachers to lead the problem-solving process, for students to focus their efforts, and for communities to understand and transform the reality and themselves (Rivarosa \& Perales, 2006).

Competence-based teaching and learning. The three experiences are focused on competence-based learningteaching. In the first two cases, the teacher motivates students to integrate multiple dimensions of knowledge (conceptual, procedural, attitudinal, communicative, and epistemic) to solve the problem. In the third case, teachers are encouraged to guide students in also using multiple perspectives from the subject-matters. Proposing real problems and articulating multiple dimensions of knowledge for the solution through projects is a way for students to build their competences and for teachers to innovate their practice (Tovar-Gálvez, 2018).

Project-based teaching and learning. In each educational process, there is an approximation to projects, as a way to make learning possible and organize the community. Focusing the teaching-learning processes from this perspective breaks with the tradition of information-emitting-teacher and the informationreceiving-student. Projects promote collective learning, integration between theory and practice, addressing real situations, decision-making, among other aspects (Álvarez, Herrejón, Morelos \& Rubio, 2010).

Assessing cooperatively and with formative purpose. In the experiences, assessment is developed from different perspectives and participants -hetero, self, and co. Students counted on clear and public criteria and tools to assess their multiple learnings, and to use this information to manage their achievements. The assessment is a metacognitive process, a regulator of the project's development, and a learning indicator. In this sense, assessment is not a punitive process, but constructive, and is part of the formative process (Bogantes and Palma, 2016).

Addressing environmental education from different educational approaches. In each case, the teacher guided environmental education from different educational approaches. This is evidence of the possibility for teachers to develop environmental education from their diverse profiles and experience. Environmental education is not an issue to only be addressed by science teachers or the didactic of science, but all teachers and all educational research fields (Briggs et al., 2018; Demoly \& Santos, 2018; Marques et.al, 2016).

Breaking institutional barriers. The main limitations 
of the experiences are in the traditional curricular conditions. The institutional administrative-directive system controls the contents and sometimes the schedule, limiting the curricular flexibility. The encouragement for institutions is to understand/manage the complex and flexible logic of environmental education and to support teachers in its integration into the curriculum (Kanyimba, Hamunyela \& Kasanda, 2014).

The systematization of experiences as a methodology. The systematization-of-experiences is an alternative to production of knowledge, enhancing the educational processes, teacher's professional development and transformation of institutions. The report by Menegaz, Cordero and Mengascini (2012) illustrates how the systematization of EE experiences in Argentina contributes to the construction of knowledge. The authors identify as emerging categories the conceptions and representations of the environment held by the teachers who participated in the educational process. Subsequently, the researchers contrast these findings with existing theory, thus contributing knowledge to the field. Martínez's (2019) work is an example of how the systematization of EE experiences in Ecuador promotes the experiences' transformation. The author first reconstructs and organizes three experiences and then discusses their strengths and weaknesses. From there, the researcher presents a feedback design for future EE seminars. The same research by Menegaz et al. (2012) makes visible how systematization was a reflective, self-critical and formative process for teachers. Finally, the report by Hernández (2014) evidences how the systematization of EE experiences in eighteen schools in Colombia leads to the institutions' transformation. The learnings identified by the author are not only aimed at improving projects, but also institutional dynamics.

By contrasting the present systematization of three EE experiences with the reports above mentioned it is possible to identify a contribution to the production of knowledge. The recovery and organization of cases have the objective of identifying common and successful practical elements. These practical elements are categories that emerge when studying the content of the narrative of each experience and assessing its pedagogical and didactic contribution. Finally, these categories are discussed or compared with other research results. The practical elements identified and discussed are potentially transferable and adaptable. Thus, the systematization displayed contributes to the expansion of environmental pedagogical and didactic knowledge.
Directed Content Analysis: Approximations To The Framework

Complex environmental pedagogical background. The three cases provide evidence of a view of the being as a self-eco-organized system. Accordingly, the teacher promotes two kinds of performances from students. Performances relative to self-organization are those in which each student uses knowledge to act in solving the problem. Performances relative to eco-organization are those in which students work as a team to act in solving the problem. This comprehension of the being is evident since the teacher a) motivates multiple learnings as conceptual, methodological, attitudinal, communicative, and epistemic, b) stimulates the cooperative work and the integration of knowledge, and c) proposes to change the environmental context. Those aspects contribute to the building of a self-eco-organized being.

Participants' roles in the educational processes is cooperative. The teacher manages this relationship through the projects. In this dynamic, students assume working roles in the teams to distribute responsibilities. Students interchange roles assuring they learn different responsibilities. Additionally, students and the teacher assess the roles, activities, learning, products, and achievements, using public criteria. These processes contribute to social learning, community organization, and regulation, and might lead to self-eco-organized institutions. Institutions are self-eco-organized systems when the participants guarantee internal and external conditions to build the citizen profile through the project. The internal or self-organized level encourages administrative, material, logistical, personal, pedagogical and didactic conditions to develop the project. The external or eco-organized level encourages connections and cooperation with other institutions and communities to develop the project.

There is an approach to integrate different kinds of knowledge to solve a problem. As was mentioned, the teacher proposes to address the subject-matter from multiple dimensions, promoting in students' multiple learnings. The hypothetical case provides evidence of an approximation to knowledge self-eco-organization. The self-organization is when the school uses different subjects-matters to understand and solve the problem. The eco-organization would be based on whether the school uses knowledge external to the curriculum. In this case, external knowledge might come from indigenous and farmer communities (Mpofu, Otulaja, \& Mushayikwa, 2014).

Complex environmental didactic background. The experiences are an approximation to the development of students' Complex Environmental Competence 
-CEC. The components supported are -a) the cognitive, because the teacher promotes multiple learning (conceptual, methodological, attitudinal, communicative and epistemic) and the integration of subject-matters, b) metacognitive, because the teacher engages students in reflecting, administrating and assessing on their learning, c) social, because the teacher organizes students' work through a cooperative project, d) contextual, because the teacher uses a local environmental problem to develop the curriculum, e) and identity, because the teacher motivates students in reflecting on their role as citizens and future professionals. The factual component of the CEC is not fully supported, because the two first experiences are focused more on understanding the problem and possible solutions, and the hypothetical case do not provide evidence.

The teacher manages the teaching process through a project with different organizational orders. The teacher defines general working phases, roles, and supporting tools to guide project development. Likewise, the teacher guides students to propose activities to enact such general working phases. Thus, there is a general order and a team order. The hypothetical case suggests another organization order between different classes and subjectmatters. When students go to places in their cities, they have the opportunity to establish a new organizational order with each community.

The assessment was diverse in terms of its participants. The students had the opportunity to do self- and co- evaluation, but with guides in which the researcher presented the criteria to guide the process. It was also possible to evaluate the teacher. Likewise, as a teacher, the researcher not only valued the performance indicators in multiple learning, but has also systematized the experiences, to reflect on them and to share them with other teachers.

The community assesses the students' learning and products cooperatively and with formative purpose. During the process, the teacher provides students with assessment tools. Therefore, students count on public criteria to self-, co-, and hetero- assess. Additionally, the assessment results are used to redesign learning activities and strategies. As a future possibility, communities might explore assessing other participants/sceneries as teachers and teaching, curriculum, institutional support, etc., which are relevant for the students learning.

Other attempts to assess the self-eco-organization of educational processes. The assessment or study of selfeco-organization in educational experiences is commonly a qualitative description of subjects' constructs and processes. For example, Fontana and Guérios (2020) propose a self-eco-organized understanding of teacher educator learning and formation. Riccardo and Lloveras (2010) develop a descriptive model of creativity as an emergence of a self-eco-organized system. And Rosado (2013), within several principles, studies the learning of students and teachers as a system that self-eco-organizes around specific situations. These research reports assume constructs or processes as systems, and their descriptive models aim to promote complex educational processes. In the cited studies, as well as in the experiences here systematized, researchers take narratives, testimonies, interviews, class observations, recordings, lesson planning, materials, and assessment results, as sources of qualitative data.

The systematized cases and those cited contribute to the construction of a complex environmental pedagogy and a complex environmental didactics. A part of this contribution is that they describe different dimensions, characteristics or scenarios of educational processes from self-eco-organization. Thereby, the studies advance in terms of frameworks on education, educational institutions, participants, curriculum, learning, teaching and assessment from a complex perspective. Another contribution is empirical. The reports present educational experiences supported by complex frameworks, and also provide emerging findings from contrasting practice and theory.

\section{REFERENCES}

ActionAid International. (2009). Resource Pack on Systematization of Experiences. Buenos Aires: GHM Grupo de Comunicación.

Abril, V. (2011). Desarrollo de la competencia ambiental en los estudiantes de la carrera de Ingeniería Industrial de la Universidad Tecnológica Indoamérica. Espiral, Revista de Docencia e Investigación, 1(1), 67-72.

Álvarez, V., Herrejón, V., Morelos, M., \& Rubio, M. (2010). Trabajo por proyectos: aprendizaje con sentido. Revista Iberoamericana de Educación, 52(5), 1-13.

Ardoin, N., Bowers, A., Wyman, N., \& Holthuis, N. (2018). Environmental education and K-12 student outcomes: A review and analysis of research. The Journal of Environmental Education, 49(1), 1-17. https://doi.org/10.1080/00958964.201 7.1366155

Arredondo, M., Saldivar, A., \& Limón, F. (2018). Educational strategies to approach environmental topics. Experiences in primary schools in Chiapas. Innovación educativa (México, DF), 18(76), 13-37.

Ausubel, D., Novak, J., \& Hanesian, H. (1978). Educational Psychology: A Cognitive View. New York: Holt, Rinehart and Winston.

Bogantes, J., \& Palma, K. (2016). Teaching and learning continuous regulation from evaluate to learn. A didactics of language department experience. Innovaciones educativas, 18(24), 59-72.

Briggs, L., Trautmann, N., \& Fournier, C. (2018). Environmental education in Latin American and the Caribbean: The challenges and limitations of conducting a systematic review of evaluation and research. Environmental Education 
Research, 24(12), 1631-1654. https://doi.org/10.1080/135046 22.2018.1499015

Burmeister, M., \& Eilks, I. (2013a). An understanding of sustainability and education for sustainable development among German student teachers and trainee teachers of chemistry. Science Education International, 24(2), 167-194.

Burmeister, M., \& Eilks, I. (2013b). Using participatory action research to develop a course module on education for sustainable development in pre-service chemistry teacher education. Center for Educational Policy Studies Journal, 3(1), 59-78.

Calvo-Cruz, X. (2013). La educación ambiental de la niñez costarricense en la edad escolar: responsabilidad compartida por el currículo oficial del ministerio de educación pública y el hogar. Biocenosis, 27(1), 14-20.

Cárdenas, N., y Suarique, E. (2010). La biblioteca comunitaria gestora de red social. Bogotá: Alcaldía Mayor de Bogotá.

Carvajal, Y. (2010). Interdisciplinary: a challenge for higher education and research. Revista Luna Azul, 31, 156-169.

Dannenberg, S., \& Grapentin. T. (2016). Education for sustainable development - learning for transformation. The example of Germany. Journal of Futures Studies, 20(3), 7-20. doi:10.6531/ JFS.2016.20(3).A7

Demoly, K. R. A, \& Santos, J. S. (2018). Learning, environmental education and school: ways of en-acting in the experience of students and teachers. Ambiente \& sociedade, 21, 2-20. doi:10.1590/1809-4422asoc0087r2vu18l1ao

Díaz, S., Mendoza, V., \& Porras, C. (2011). Una guía para la elaboración de estudios de caso. Razón y palabra, 75, 1-25.

Dyment, J., Hill, A. \& Emery, S. (2015). Sustainability as a crosscurricular priority in the Australian Curriculum: a Tasmanian investigation. Environmental Education Research, 21(8), 1105-1126, DOI: 10.1080/13504622.2014.966657

Erdoğan, M., Kostova, Z., Marcinkowski, T. (2009). Components of environmental literacy in elementary science education curriculum in Bulgaria and Turkey. Eurasia Journal of Mathematics, Science and Technology Education, 5(1), 15-26.

Eschenhagen, M. (2011). The environmental issue and the environmental education in universities: some indicators and reflections. Revista de Educación y Desarrollo, 19, 35-41.

Falkembach, E., \& Carillo, A. T. (2015). Systematization of experiences: A practice of participatory research from Latin America. In Bradbury, H. The SAGE Handbook of action Research (pp. 76-82). London: SAGE Publications Ltd. DOI: $10.4135 / 9781473921290$

Fuentes, N., \& González, H. (2016). Greening of university curriculum: a challenge of ecopedagogy. Tecné, Episteme y Didaxis, 40, 310-339.

Geli, A., Collazo, L., \& Mulà, I. (2019). The evolution of embedding sustainability in the higher education curriculum in Spain. Revista de educación ambiental y sostenibilidad 1(1), 1102.

Gutiérrez, J., \& González, A. (2005). Ambientalizar la universidad: un reto institucional para el aseguramiento de la calidad en los ámbitos curriculares y de la gestión. Revista Iberoamericana de Educación, 36(7), 1-14.

Gutierrez-Sabogal, L. (2015). Problematic of the environmental education in educational institutions. Revista científica, 3(23), 57-76.

Hernández, T. (2014). Sistematización de experiencias del proyecto "escuelas protectoras del medio ambiente" lecciones aprendidas. Fundación Corona, Fundación PLAN, UNICEF: Bogotá.

Hsieh, H-F \& Shannon, S. E. (2005). Three approaches to qualitative content analysis. Qualitative Health Research, 15(9):1277-88.

Jara, O. (2012). Systematization of experiences, research and evaluation: three different approaches. The international journal for global and development education research, 1, 71-84.

Kanyimba, A., Hamunyela, M., \& Kasanda, Ch. D. (2014). Barriers to the implementation of education for sustainable development in Namibia's higher education institutions. Creative Education, 5, 242-252.

Khademi-Vidra, A. (2017). Curriculum planning of the environmental education. Journal of Central European Green Innovation, 5(1), 65-80.

Marques, R., Gonzalez, C.E.F., \& Xavier, C.R. (2016). As dificuldades da inserção e da prática em educação ambiental no currículo escolar. VXI Encontro Paranaense de Educação Ambiental. Paraná.

Martínez, V. (2019). Systematization of environmental educative experiences in tourism. Revista Electrónica Cooperación Universidad Sociedad, 4(3), 43-54.

Mejías, J. J. (2015). La colaboración docente en el marco de los equipos didácticos de ciclo: estudio de caso. Revista internacional de organización educativa y liderazgo, 2(1), 3748.

Menegaz, A., Cordero, S.\& Mengascini, A. (2012). Sistematización de una experiencia de educación ambiental en la formación docente continua: representaciones, ambiente y análisis colaborativo. Revista Electrónica de Enseñanza de las Ciencias, 11(3), 660-677.

Meyers, R. (2006). Environmental learning: reflections on practice, research and theory. Environmental Education Research,12(3-4),459-470,DOI:10.1080/13504620600799216

Mora, W. (2015). Capacity development and training of competences environment in teachers of science. Tecné, Episteme y Didaxis, 38(2), 185-203.

Morin, E. (1996). Thought ecologized. Gazeta de Antropología, 12, 1-7.

Morin, E. (1998). Introducción al pensamiento complejo. Barcelona: Gedisa.

Morin, E. (1999). Seven complex lessons in education for the future. Paris: UNESCO.

Morin, E. (2004). Epistemology of complexity. Gazeta de Antropología, 20, 1-15.

Morón, F. (2015). La importancia de hacer buenas preguntas a nuestros alumnos de la ESO. Revista Arista Digital, 54, 1-12. Retrieved from https://bit.ly/2vD3q1Q

Mpofu, V., Otulaja, F., \& Mushayikwa, E. (2014). Towards culturally relevant classroom science: a theoretical framework focusing on traditional plant healing. Cultural studies of science education, 9, 221-242. 10.1007/s11422-0139508-5

Oliveira, J. A., \& Sá, P. A. P. (2017). Pensar em competências para o desenvolvimento sustentável e sustentabilidade: uma análise frente aos desafios do século XXI. Educação Ambiental em Ação, 61, 1-17.

Paredes-Chi, A., \& Viga-de Alva, M. (2018). Environmental education (EE) policy and content of the contemporary (2009-2017) Mexican national curriculum for primary schools. Environmental Education Research, 24(4), 546-580.

Parga, D., \& Mora, W. (2016). Environmental didactics and educational knowledge of content in chemistry. Indagatio Didactica, 8(1), 777-792. https://doi.org/10.34624/ id.v8i1.3487

Puerto Layton, C. M., \& Tovar-Gálvez, J. C. (2020). Proposal for an assessment system of environmental education processes based on complexity expressions scenarios. Revista Internacional De Formação De Professores, 5, e020029, 1-25. Retrieved from https://bit.ly/2HUlu1u

Restrepo, K. P. (2013). La exclusión de la contaminación 
hídrica dentro del currículo educativo. Nousitz: Revista de investigación científica y tecnológica, 54, 39-51.

Rivarosa, A., \& Perales, F. (2006). La resolución de problemas ambientales en la escuela y en la formación inicial de maestros. Revista Iberoamericana de Educación, 40, 111-124.

Sanuca, M. (2018). The environmental education, a challenge for the professional's formation in Angola. VARONA, Revista Científico-Metodológica, 67, 1-10.

Solbes, J., \& Vilches, A. (2004). Papel de las relaciones entre ciencia, tecnología, sociedad y ambiente en la formación ciudadana. Enseñanza de las Ciencias, 22(3), 337-348.

Stevenson, R. B. (2007). Schooling and environmental/ sustainability education: from discourses of policy and practice to discourses of professional learning. Journal Environmental Education Research, 13(2), 265-285. Retrieved from doi:10.1080/13504620701295650

Tian, Y., \& Wang, Ch. (2016). Environmental education in China: development, difficulties and recommendations. Journal of social science studies, 3(1), 31-43.

Torres, L., Mesina, N., Salamanca, B., \& Sepúlveda, C. (2016). Effect of the interdisciplinary teaching of environmental education on knowledge, values and attitude of junior high school students (Los Ángeles city, Biobio Region, Chile). Revista Complutense de Educación, 27(3), 1139-1155. doi:10.5209/rev_RCED.2016.v27.n3.47551

Tovar-Gálvez, J. C. (2012). Metacognición y Didáctica de las Ciencias: integración de procesos de enseñanza, procesos metateóricos y competencias. Saarbrücken: Editorial Académica Española.

Tovar-Gálvez, J. C. (2013). Pedagogía ambiental y didáctica ambiental como fundamentos del currículo para la formación ambiental. Revista Brasileira de Educação, 18(55), 877-898. DOI: 10.1590/S1413-24782013000400005

Tovar-Gálvez, J. C. (2018). Transformaciones de la docencia para una formación por competencias en ciencias. In: TovarGálvez, J. C. (Ed). Trends and challenges in Higher Education in Latin America (1-10). Eindhoven: Adaya Press. Retrieved from https://bit.ly/2YUDjma

Tovar-Gálvez, J. C. (2020a). Currículo de educación ambiental desde la complejidad: construcción de la competencia ambiental a través de proyectos. In: Hernández, A., Ramírez, R., \& Escobar, O. (Eds). Educación ambiental en el siglo XXI: del trayecto de construcción a la imperiosa necesidad (105140). Hermosillo: CONACYT. Retrieved from https://bit. ly/2W8z0SP

Tovar-Gálvez, J. C. (2020b). Reducing the gap between theory and practice during the pandemic: planning a complex virtual environmental project. Revista Internacional De Pesquisa Em Didática Das Ciências E Matemática, 1, e020017, 1-22. Retrieved from https://bit.ly/32Qmz0q

Tovar-Gálvez, J. C., \& Cárdenas, N. (2012). La importancia de la formación estratégica en la formación por competencias: evaluación de las estrategias de acción para la solución de problemas. Revista Electrónica de Investigación Educativa, 14(1), 122-135. Retrieved from https://bit.ly/31MxTeH

Tovar-Gálvez, J. C., Téllez-Acosta, M., \& Martínez, D. (2017). Inclusive environmental education for civil society in multicultural cities. Adult Education and Development, 84, 85-89. Retrieved from https://bit.ly/3lDZQgS

Vásquez, E., Becerra, A., \& Ibáñez, S. (2014). Directed research as strategy for development of science skills. Revista científica, 18, 75-85.

Winter, J., \& Cotton, C. (2012). Making the hidden curriculum visible: Sustainability literacy in higher education. Environmental Education Research, 18(6), 783-796,
$10.1080 / 13504622.2012 .670207$ 